\title{
EFFECT OF DIFFERENT SOLVENTS ON ANTIOXIDANT ACTIVITY OF LEAF EXTRACTS OF CALOTROPIS PROCERA AND AZADIRACHTA INDICA
}

\author{
SHARMISTHA BANERJEE, SHUCHI KAUSHIK, RAJESH SINGH TOMAR* \\ Amity Institute of Biotechnology, Amity University, Madhya Pradesh, Gwalior, India. Email: rstomar@amity.edu
}

Received: 10 September 2016, Revised and Accepted: 04 October 2016

\section{ABSTRACT}

Objective: This study was performed to identify the phytochemicals and comparatively evaluate the antioxidant activity of Calotropis procera and Azadirachta indica by detection of total phenolics, hydrogen peroxide radical scavenging activity, and estimation of condensed tannins in different solvent systems and at different temperatures.

Methods: Leaves of $C$. procera and $A$. indica were extracted in water, methanol by soaking dried leaf powder at room temperature and also by boiling the leaf powder in water for 30 minutes. Phytochemical tests were performed in all of the extracts. The antioxidant activity was determined by hydrogen peroxide radical scavenging activity. Quantitative estimation of total phenolics and hydrolysable tannins was also performed.

Results: The total phenolics in both leaf extracts was obtained maximum in boiled extract (40.7 $\pm 1.20 \mathrm{mg}$ gallic acid equivalent [GAE]/g dry extract in $C$. procera and $33.66 \pm 1.45 \mathrm{mg} \mathrm{GAE} / \mathrm{g}$ dry extract in $A$. indica). The amount of hydrolysable tannins in both leaf extracts was found to be highest in methanol (150 $\pm 1.88 \mathrm{mg}$ catechin equivalent/g dry extract in $C$. procera and $144.8 \pm 2.63 \mathrm{mg}$ catechin equivalent/g dry extract in $A$. indica).

Conclusion: The study showed promising results indicating that these plants are a good source of antioxidants. The majority of phytochemicals were extracted in distilled water and methanol acts as a good solvent for extraction of tannins, whereas an increase in temperature leads to poor extraction of tannins.

Keywords: Antioxidant, Phytochemicals, Phenolics, Radical, Tannins.

(C) 2017 The Authors. Published by Innovare Academic Sciences Pvt Ltd. This is an open access article under the CC BY license (http://creativecommons. org/licenses/by/4. 0/) DOI: http://dx.doi.org/10.22159/ajpcr.2017.v10i1.15145

\section{INTRODUCTION}

Numerous scientific studies indicate that during oxidative stress, oxygen radicals such as hydroxyl radical $(\mathrm{OH})$, peroxyl radicals hydrogen peroxide $\left(\mathrm{H}_{2} \mathrm{O}_{2}\right)$, and superoxide anion $\left(\mathrm{O}^{2-}\right)$ are generated in living systems which are commonly known as reactive oxygen species. These free radicals may cause oxidative damage to biomolecules such as DNA, lipids, and proteins. They also play a significant role in many degenerative diseases such as cardiovascular diseases, cancer, ageing, Alzheimer's and several other neurodegenerative disorders [1-4]

Numerous researches indicate that the antioxidants in fruits and vegetable play a major role in reducing the incidence of chronic diseases including heart disease and some cancers [5-8]. An antioxidant is any substance that delays or stops oxidative damage [9]. Antioxidant has the ability to remove free radicals by acting as hydrogen donors and quenchers of singlet oxygen $[10,11]$. The purpose of using antioxidants as therapeutic agents is to lower the oxidative stress by preventing or delaying the development of disease or reversing some of the complicacies associated with oxidative stress [12].

The use of plants, plant extracts, and pure compounds isolated from natural sources has always provided a basis for modern pharmaceutical compounds [13]. Plants have been a rich source of medicines as they produce a variety of bioactive compounds, majority of which probably evolved as a chemical defense against predation or infection [14]. Phyto is the Greek word for plants. There are many "families" of phytochemicals which help the human body in many ways. Phytochemicals are nonnutritive plant chemicals that have protective or disease preventive properties. Plants produce these chemicals to protect themselves, but recent research shows that many phytochemicals have the potential to provide protection against human diseases [15].
In recent decades, many researchers are interested in medicinal plants for evaluation of antioxidant phytochemicals such as phenols, flavonoids, and tannins which have got enormous attention because of their potential in preventing many human diseases [16]. Calotropis procera belonging to the family: Asclepiadaceae, commonly called as "aak" in India is used as an herbal medicine by human since time immemorial. It has numerous biological activities and hence can act as anti-inflammatory, analgesic, antidiabetic, antioxidant, antiarthritic, antihelminthic, wound healer, anticandidal, anticonvulsant, antiasthmatic, hepatoprotective, and antitumor agent [17]. Azadirachta indica popularly known as neem is evenly spread in India and its neighboring countries since ancient times as one of the most potent medicinal plants having wide spectrum biological activity [18] Neem oil, leaves, bark, and stem products have been therapeutically used for the treatment of respiratory disorder, inflammation, constipation, skin infection [19], arthritic disorders, fever and diabetes, etc. [20]. Apart from these, there are several reports on pharmaceutical and biological activities of neem based on the scientific investigation such as antibacterial antifungal, antiviral, and antioxidant activities [21].

It is well-recognized that different solvents have the ability to extract different types of phytochemicals on the basis of their polarity; henceforth, the biological activity of the extracts can be varied [22-24]. Alcohol extracts are more preferable over water extracts in many pharmacological assays, since lipophilic bioactive secondary metabolites; usually phenolics are more easily extracted with alcohol than with water [25]. In addition to the phytochemicals found in alcoholic extracts, hot water or boiled water also tends to extract other biological components [26,27].

This study was done to investigate the phytochemicals present in leaf extracts of $C$. procera and $A$. indica, effect of different solvents on the extraction of phytochemicals as well as on its antioxidant activity. 


\section{METHODS}

\section{Sample collection}

Fresh leaves of $C$. procera and A. indica were collected from Amity University campus, Madhya Pradesh. The plants were authenticated by botany professor, Dr. Sushil Kumar Sharma, Assistant Professor, Amity University, Gwalior, Madhya Pradesh, India. The leaves were washed thoroughly with tap water to remove the dust particles. Then, the leaves were kept in shade and spread evenly for drying until they become crispy. Dried leaves were ground to fine powder in pestle and mortar. The powder was stored in air tight polythene bags until further use.

\section{Preparation of extract}

About $1 \mathrm{~g}$ of powdered leaf (C. procera and A. indica) was soaked separately in $10 \mathrm{ml}$ of distilled water and methanol and kept for $72 \mathrm{hrs}$ at room temperature. Then, the mixture was centrifuged at $3000 \mathrm{rpm}$ for 10 minutes. The supernatant was collected and stored in refrigerator at $4^{\circ} \mathrm{C}$ for further activity analysis.

Aqueous boiled extract was also prepared by boiling $5 \mathrm{~g}$ of dried leaf powder in $100 \mathrm{ml}$ of distilled water for 30 minutes. Then, it was filtered using cheese cloth and stored at $4^{\circ} \mathrm{C}$ for further analysis.

\section{Phytochemical screening}

The plant extracts were evaluated qualitatively for different phytochemicals by protocol given by Harborne in 1984 with certain modifications [28].

\section{Tri-terpenoids}

About $500 \mu \mathrm{l}$ of leaf extracts (C. procera and A. indica) prepared in all solvent system was pipetted in three different test-tubes and was dissolved in $200 \mu \mathrm{l}$ of chloroform, thereafter equal volume of concentrated sulfuric acid was added slowly along the wall of the testtube. A brown/red/purple ring at the interface indicates the presence of steroids.

\section{Tannins}

About $100 \mu \mathrm{l}$ of leaf extracts (C. procera and A. indica) prepared in all solvent system was pipetted in three different test-tubes and few drops of $1 \%$ lead acetate were added to each of the test-tubes. A yellowish precipitate indicates the presence of tannins.

\section{Saponins}

About $100 \mu \mathrm{l}$ of leaf extracts (C. procera and A. indica) prepared in all solvent system was pipetted in three different test-tubes and $4 \mathrm{ml}$ of distilled water was added in each test-tubes. The mixture was then shaken vigorously for 30 seconds. Then, it was left undisturbed for few minutes. The presence of intense foam indicated that saponins are present.

\section{Leucoanthocyanins}

About $100 \mu \mathrm{l}$ of leaf extracts (C. procera and A. indica) prepared in all solvent system was pipetted in three different test-tubes and $100 \mu \mathrm{l}$ of iso amyl alcohol was added to each test-tubes. The appearance of red color in the upper layer indicates the presence of leucoanthocyanins.

\section{Coumarins}

About $100 \mu \mathrm{l}$ of leaf extracts (C. procera and A. indica) prepared in all solvent system was pipetted in three different test-tubes and then to each of the test-tubes $150 \mu \mathrm{l}$ of $10 \% \mathrm{NaOH}$ was added. The appearance of yellow color indicates the presence of coumarins.

\section{Flavonoids}

About $100 \mu \mathrm{l}$ of prepared leaf extracts (C. procera and A. indica) in all solvent system was pipetted in three different test-tubes, and then, $10 \mu \mathrm{l}$ of $1 \% \mathrm{NaOH}$ was added to each of the test-tubes. On appearance of intense yellow color, $10 \mu \mathrm{l}$ of concentrated $\mathrm{HCl}$ was further added. Reversion to original color of the extract indicated the presence of flavonoids.

\section{Total phenols}

Total phenols were determined by Folin-Ciocalteu reagent method [29]. $500 \mu \mathrm{l}$ of extract (C. procera and A. indica, concentration: $1: 10 \mathrm{~g} / \mathrm{ml}$ ) in different solvent systems was added in separate test-tubes. Then, $5 \mathrm{ml}$ of Folin-ciocalteu reagent (1:10 diluted with distilled water) was added to each of the test-tubes followed by addition of $4 \mathrm{ml}$ of $1 \mathrm{M} \mathrm{Na}_{2} \mathrm{CO}_{3}$. The mixture was allowed to incubate at $37^{\circ} \mathrm{C}$ for 30 minutes. Then, the absorbance was measured at $710 \mathrm{~nm}$ against blank. A standard graph of gallic acid was plotted (Concentration $[\mu \mathrm{g} / \mathrm{ml}]$ vs. optical density) from a stock solution of $500 \mu \mathrm{g} / \mathrm{ml}$ to determine the concentration of total phenolics. The total phenolics content was expressed as mg gallic acid equivalent (GAE)/g dry weight. The equation from standard graph of gallic acid is as follow:

Absorbance $=0.0098 \mu$ g gallic acid $+0.0104 ; R^{2}=0.9903$.

\section{Hydrolysable tannins}

Hydrolysable tannins were quantitatively estimated by the method devised by Bate-Smith in 1977 with slight modifications [30]. $1.5 \mathrm{ml}$ of plant extract (C. procera and A. indica) was mixed with $500 \mu \mathrm{l}$ of saturated potassium iodide. The mixture was allowed to stand at room temperature for 40 minutes. Then, the absorbance was read at $550 \mathrm{~nm}$ against saturated potassium iodide as blank. The hydrolysable tannins were expressed as mg equivalent catechin/g dry weight. The quantity in mg equivalent of catechin was obtained by the standard equation:

\section{Absorbance $=0.8264 \mathrm{mg}$ catechin $+0.0392 ; \mathrm{R}^{2}=0.9155$.}

\section{$\mathrm{H}_{2} \mathrm{O}_{2}$ radical $\left(\% \mathrm{H}_{2} \mathrm{O}_{2}\right)$ scavenging activity}

The radical scavenging activity of $\mathrm{H}_{2} \mathrm{O}_{2}$ in plant extracts of different solvent system was determined by protocol devised by Ruch et al. in 1989 with certain modifications [31]. $1 \mathrm{ml}$ of extract was mixed with $2 \mathrm{ml}$ of $20 \mathrm{mM} \mathrm{H}_{2} \mathrm{O}_{2}$ prepared in phosphate buffer saline (pH 7.4). The mixture was incubated at $37^{\circ} \mathrm{C}$ for 10 minutes. The absorbance was read at $230 \mathrm{~nm}$ against blank. $\% \mathrm{H}_{2} \mathrm{O}_{2}$ activity was determined by:

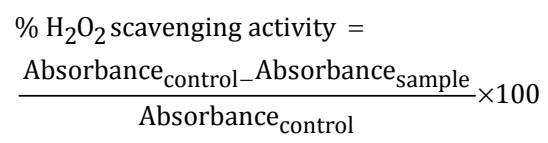

\section{RESULTS AND DISCUSSION}

The results of this study are summarized under the following sub headings.

\section{PHYTOCHEMICAL SCREENING}

Preliminary phytochemical screening of tri-terpenoids, tannins, saponins, leucoanthocyanins, coumarins, and flavonoids for both $A$. indica and C. procera were performed, and the results are shown in Tables 1 and 2, respectively.

\section{Total phenolics (mg GAE/g extract)}

The total phenolics were obtained maximum in boiled extract $(40.7 \pm 1.20 \mathrm{mg} \mathrm{GAE} / \mathrm{g}$ dry extract), then in methanol $(26.43 \pm 1.41 \mathrm{mg}$ GAE/g dry extract), and $21.39 \pm 0.83 \mathrm{mg} \mathrm{GAE} / \mathrm{g}$ dry extract in leaf extracts of distilled water of $C$. procera (Fig. 1). The total phenolics in leaf extracts of $A$. indica was found to be maximum in boiled extract (33.66 $\pm 1.45 \mathrm{mg} \mathrm{GAE} / \mathrm{g}$ dry extract), then in methanol $(25.44 \pm 0.7 \mathrm{mg}$ GAE/g dry extract) and $15.48 \pm 1.65 \mathrm{mg} \mathrm{GAE} / \mathrm{g}$ dry extract in distilled water (Fig. 2). The results are in accordance with a study conducted by Susanti et al. in 2015 [32] and they concluded that as temperature increases water polarity decreases, making the conditions favorable for extraction of phenol. This indicates that treating the leaf with distilled water at elevated temperature might result in easy extraction of phenolics which may eliminate the use of other toxic organic solvents. 
Table 1: Phytochemical evaluation of $A$. indica

\begin{tabular}{|c|c|c|c|c|c|c|}
\hline Tests & Tri-terpenoids & Tannins & Saponins & Leuco-anthocyanins & Coumarins & Flavonoids \\
\hline \multicolumn{7}{|l|}{ Solvents } \\
\hline Distilled water & + & + & - & + & + & + \\
\hline Boiled extract & - & + & - & - & + & + \\
\hline
\end{tabular}

+ indicates presence and - indicates absence. A. indica: Azadirachta indica

Table 2: Phytochemical evaluation of $C$. procera

\begin{tabular}{|c|c|c|c|c|c|c|}
\hline Tests & Tri-terpenoids & Tannins & Saponins & Leuco-anthocyanins & Coumarins & Flavonoids \\
\hline \multicolumn{7}{|l|}{ Solvents } \\
\hline Distilled water & + & + & + & - & + & - \\
\hline Methanol & - & - & - & - & - & - \\
\hline Boiled extract & - & + & + & - & + & - \\
\hline
\end{tabular}

+ indicates presence and - indicates absence. C. procera: Calotropis procera

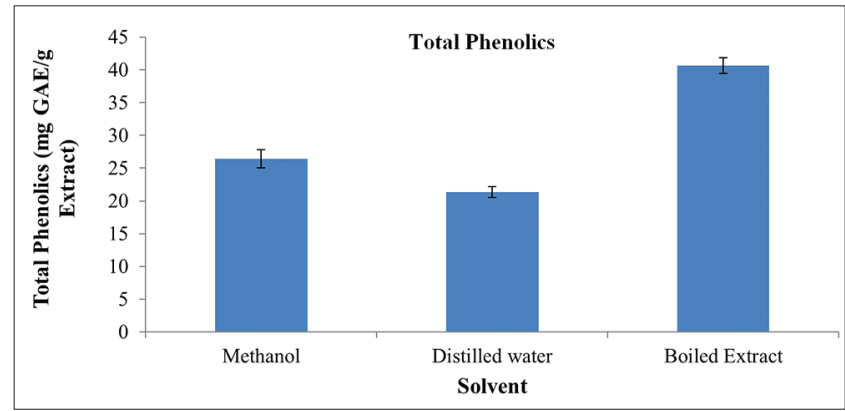

Fig. 1: Comparative analysis of total phenolics (mg gallic acid equivalent/g extract) in Calotropis procera in different solvent system. All experiments were performed in triplicates and the results are expressed in mean values \pm standard deviation

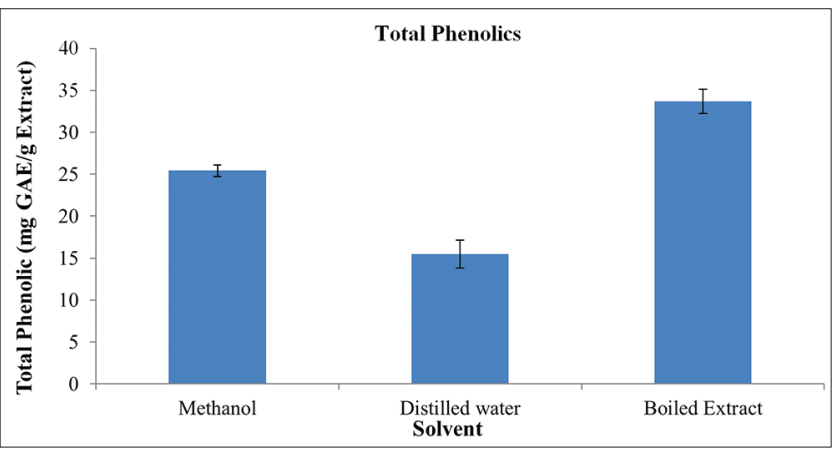

Fig. 2: Comparative analysis of total phenolics (mg gallic acid equivalent/g extract) in Azadirachta indica in different solvent system. All experiments were performed in triplicates and the results are expressed in mean values \pm standard deviation

\section{Hydrolysable tannins}

Tannins are complex secondary metabolites and pose many medicinal properties [33]. The amount of hydrolysable tannins in leaf extracts of C. procera was found to be maximum in methanol $(150 \pm 1.88 \mathrm{mg}$ catechin equivalent/g dry extract) followed by distilled water $(130.46 \pm 1.48 \mathrm{mg}$ catechin equivalent/g dry extract) and boiled extract $(24.46 \pm 0.98 \mathrm{mg}$ catechin equivalent/g dry extract) (Fig. 3). The hydrolysable tannin content in leaf extracts of $A$. indica was found to be highest in methanol $(144.8 \pm 2.63 \mathrm{mg}$ catechin equivalent/g dry extract) and almost in similar amount in distilled water $(9.67 \pm 2.05 \mathrm{mg}$ catechin equivalent/g dry extract) and boiled extract $(7.66 \pm 1.25 \mathrm{mg}$ catechin equivalent/g dry extract) (Fig. 4). This indicates that methanol acts as a good solvent for

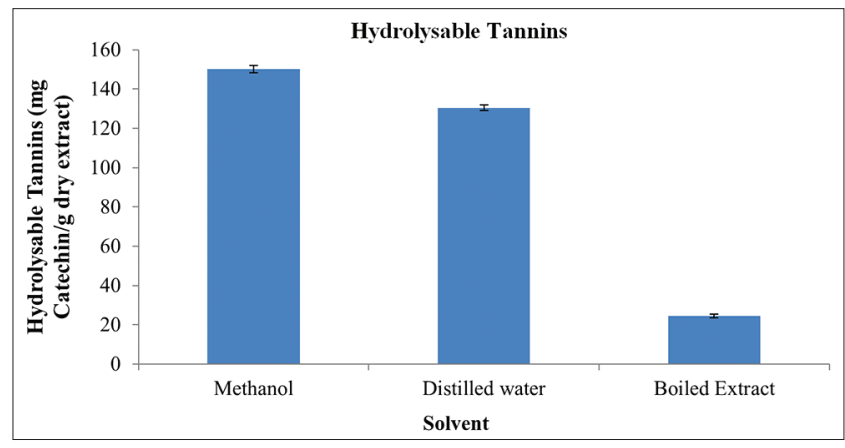

Fig. 3: Comparative analysis of hydrolysable tannins in Calotropis procera in different solvent system. All experiments were performed in triplicates and the results are expressed in mean values \pm standard deviation

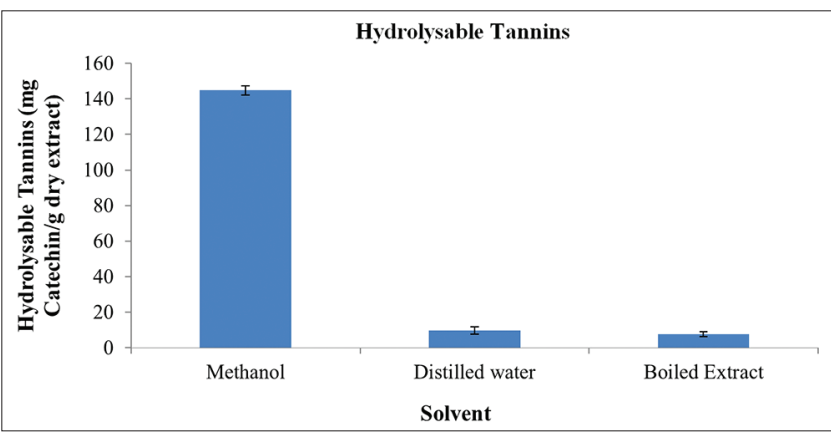

Fig. 4: Comparative analysis of hydrolysable tannins in Azadirachta indica in different solvent system. All experiments were performed in triplicates and the results are expressed in mean values \pm standard deviation.

extraction of hydrolysable tannins, whereas treating the leaf powder at elevated temperature may degrade tannins and hence the amount of hydrolysable tannins was found to be minimum in boiled extracts.

$\mathrm{H}_{2} \mathrm{O}_{2}$ radical scavenging $\left(\% \mathrm{H}_{2} \mathrm{O}_{2}\right)$ activity

$\% \mathrm{H}_{2} \mathrm{O}_{2}$ scavenging activity in leaf extracts of $C$. procera was observed maximum in distilled water $(17.99 \pm 0.57 \%)$, then almost similar amount of activity was observed in boiled extract $(17.93 \pm 0.23 \%)$ and in methanol (17.44 $\pm 1.01 \%$ ) (Fig. 5). $\% \mathrm{H}_{2} \mathrm{O}_{2}$ scavenging activity in leaf extracts of $A$. indica was observed in very less amount in boiled extract $(8.83 \pm 1.20 \%)$, and no scavenging activity was present in distilled water 


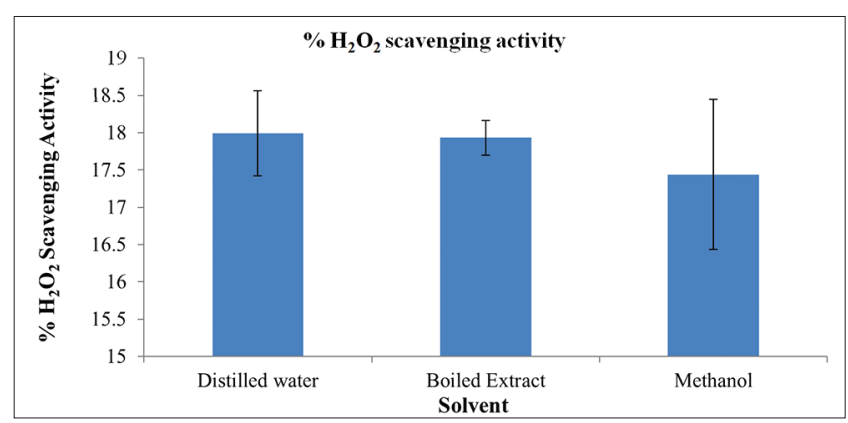

Fig. 5: Comparative analysis of $\%$ hydrogen peroxide scavenging activity in Calotropis procera in different solvent system. All experiments were performed in triplicates and the results are expressed in mean values \pm standard deviation

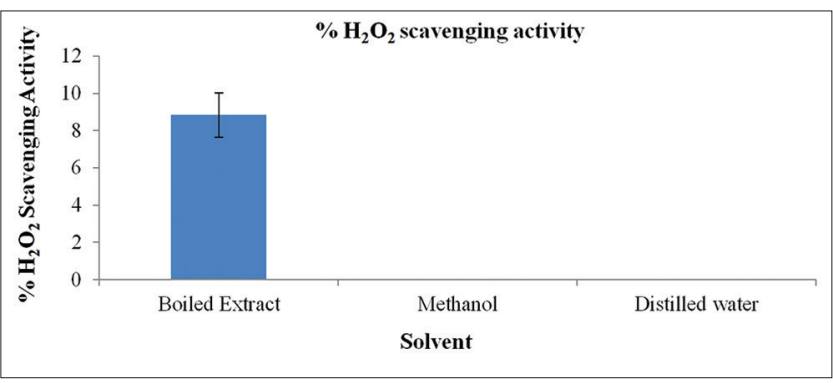

Fig. 6: Comparative analysis of \% hydrogen peroxide scavenging activity in Azadirachta indica in different solvent system. All experiments were performed in triplicates and the results are expressed in mean values \pm standard deviation

and methanol (Fig. 6). $\mathrm{H}_{2} \mathrm{O}_{2}$ as such is not that reactive but it may cause toxicity to cells because of production of hydroxyl radicals [34]. Thus, removal of $\mathrm{H}_{2} \mathrm{O}_{2}$ is very much essential for antioxidant defense in cell or food systems [35]. Thus, it could be inferred that scavenging activity of $\mathrm{H}_{2} \mathrm{O}_{2}$ in leaf extracts may be due to the presence of antioxidants.

\section{CONCLUSION}

This study showed the presence of antioxidant compounds (phenolic acids and tannins) and demonstrated some level of antioxidant activities in A. indica and C. procera. Total amount of hydrolysable tannins was found to be maximum in methanol extracts followed by distilled water and minimum in boiled extract in leaf extracts of both the plant ( $A$. indica and $C$. procera). Thus, it could be inferred that methanol acts as a better solvent for extraction of hydrolysable tannins and minimum amount of tannins in boiled extract may be due to degradation of hydrolysable tannins at elevated temperature. Total phenolics were obtained in maximum amount in boiled extracts of $A$. indica and $C$. procera. This indicates that treating the leaf powder with solvents at elevated temperature might result in easy extraction of phenolics. \% $\mathrm{H}_{2} \mathrm{O}_{2}$ radical scavenging activity was observed maximum in distilled water in C. procera and in boiled extract in A. indica. Hence, we could conclude that maximum extraction of total phenolics could be achieved either in boiled extract or aqueous solvents and also it could be a better source of antioxidant. The leaf extracts showed antioxidant activities quantitatively comparable to that of gallic acid. It may be concluded from the phytochemical and quantitative tests that both the leaf extracts of $A$. indica and $C$. procera has certain bioactive components that pose antioxidant activity and the extraction of these components depends on the type of the solvent used for extraction and also the temperature of extraction.

\section{ACKNOWLEDGMENT}

We would like to acknowledge Dr. Ashok K Chauhan, Founder president, Dr. Aseem K Chauhan, Additional President and Lt. Gen V K Sharma, Vice chancellor of the university for providing the necessary support.

\section{REFERENCES}

1. Ames BN, Shigenaga MK, Hagen TM. Oxidants, antioxidants, and the degenerative diseases of aging. Proc Natl Acad Sci U S A 1993;90(17):7915-22.

2. Pangjit K, Tantiphaipunwong P, Sajjapong W, Srichairatanakool S. Iron-chelating, free radical scavenging and anti-proliferative activities of Azadirachta indica. J Med Assoc Thai 2014;97 Suppl 4:S36-43.

3. Gey KF. The antioxidant hypothesis of cardiovascular disease: Epidemiology and mechanisms. Biochem Soc Trans 1990;18(6):1041-5.

4. Smith MA, Perry G, Richey PL, Sayre LM, Anderson VE, Beal MF, et al. Oxidative damage in Alzheimer's. Nature 1996;382(6587):120-1.

5. Salah N, Miller NJ, Paganga G, Tijburg L, Bolwell GP, Rice-Evans C. Polyphenolic flavanols as scavengers of aqueous phase radicals and as chain-breaking antioxidants. Arch Biochem Biophys 1995;322(2):339-46.

6. Gerber M, Boutron-Ruault MC, Hercberg S, Riboli E, Scalbert A, Siess MH. Food and cancer: State of the art about the protective effect of fruits and vegetables. Bull Cancer 2002;89(3):293-312.

7. Kris-Etherton PM, Hecker KD, Bonanome A, Coval SM, Binkoski AE, Hilpert KF, et al. Bioactive compounds in foods: Their role in the prevention of cardiovascular disease and cancer. Am J Med 2002;113 Suppl 9B:71S-88.

8. Serafini M, Bellocco R, Wolk A, Ekström AM. Total antioxidant potential of fruit and vegetables and risk of gastric cancer. Gastroenterology 2002;123(4):985-91.

9. Yamagishi S, Matsui T. Nitric oxide, a Janus-faced therapeutic target for diabetic microangiopathy - Friend or foe? Pharmacol Res 2011;64(3):187-94.

10. Wu YY, Li W, Xu Y, Jin EH, Tu YY. Evaluation of the antioxidant effects of four main theaflavin derivatives through chemiluminescence and DNA damage analyses. J Zhejiang Univ Sci B 2011;12(9):744-51.

11. Anokwuru CP, Esiaba I, Ajibaye O, Adesuyi AO. Polyphenolic content and antioxidant activity of Hibiscus sabdariffa calyx. Res J Med Plant 2011;5(5):557-66.

12. Kala SC. A review on phytochemical and pharmacological significance of Canthium parviflorum Lam. Int J Curr Pharm Res 2016;8(1):1-3.

13. Murti Y, Yogi B, Pathak D. Pharmacognostic standardization of leaves of Calotropis procera (Ait.) R. Br. (Asclepiadaceae). Int J Ayurveda Res 2010;1(1):14-7.

14. Ramaprabha M, Vasantha K. Phytochemical and antibacterial activity of Calotropis procera (Ait.) R. Br. Flowers. Int J Pharm Biosci 2012;3(1):1-6.

15. Srivastava M, Kumar A, Pal M. Phytochemical investigation on Jatropha curcas seed cake. Int J Pharm Life Sci 2010;1(6):357-62.

16. Upadhyay NK, Kumar MS, Gupta A. Antioxidant, cytoprotective and antibacterial effects of sea buckthorn (Hippophae rhamnoides L.) Leaves. Food Chem Toxicol 2010;48(12):3443-8.

17. Srividya BY, Ravishankar K, Bhandhavi PP. Evaluation of in-vitro antioxidant activity of Calotropis procera fruit extract. Int J Res Pharm Chem 2013;3(3):573-8.

18. Deka H, Das S, Lahan JP, Yadav RN. In-vitro free radical scavenging, antioxidant and antibacterial activity of Azadirachta indica A. Juss. of Assam. Adv Life Sci 2013;3(1):1-4.

19. Sithisarn P, Supabphol R, Gritsanapan W. Comparison of free radical scavenging activity of Siamese neem tree (Azadirachta indica A. Juss var. Siamensis valeton) leaf extracts prepared by different methods of extraction. Med Princ Pract 2006;15(3):219-22.

20. Van Der Nat MG, Van Der Sluis K, Labadie RP. Ethnopharmacognostical survey of Azadirachta indica A. Juss (Meliaceae). J Ethnopharmacol 1991;35(1):1-24.

21. Biswas K, Chattopadhyay I, Banerjee RK, Bandyopadhyay U. Biological activities and medicinal properties of neem (Azadirachta indica). Curr Sci 2002;82(11):1336-45. 
22. Soares MO, Alves RC, Pires PC, Oliveira MB, Vinha AF. Angolan Cymbopogon citratus used for therapeutic benefits: Nutritional composition and influence of solvents in phytochemicals content and antioxidant activity of leaf extracts. Food Chem Toxicol 2013;60:413-8

23. Zarnowski R, Suzuki Y. Expedient Soxhlet extraction of resorcinolic lipids from wheat grains. J Food Compost Anal 2004;17(5):649-63.

24. Wang LJ, Weller CL. Recent advances in extraction of nutraceuticals from plants. Trends Food Sci Technol 2006;17(6):300-12.

25. Cieniak C, Walshe-Roussel B, Liu R, Muhammad A, Saleem A, Haddad PS, et al. Phytochemical comparison of the water and ethano leaf extracts of the cree medicinal plant, Sarracenia purpurea L. (Sarraceniaceae). J Pharm Pharm Sci 2015;18(4):484-93.

26. Spigno G, Trarnelli L, De Faveri DM. Effects of extraction time, temperature and solvent on concentration and antioxidant activity of grape marc phenolics. J Food Eng 2007;81(1):200-8.

27. Sharma M, Arnason JT, Burt A, Hudson JB. Echinacea extracts modulate the pattern of chemokine and cytokine secretion in rhinovirus infected and uninfected epithelial cells. Phytother Res 2006;20(2):147-52.

28. Harborne JB. Phytochemical Methods - A Guide to Modern Techniques of Plant Analysis. $2^{\text {nd }}$ ed. London: Chapman and Hall; 1984
29. McDonald S, Prenzler PD, Autolovich M, Robards K. Phenolic content and antioxidant activity of olive extracts. Food Chem 2001;73(1):73-84.

30. Bate-Smith EC. Astringent tannins of Acer species. Phytochemistry 1977;16(9):1421-6.

31. Ruch RJ, Cheng SJ, Klaunig JE. Prevention of cytotoxicity and inhibition of intercellular communication by antioxidant catechin isolated from Chinese green tea. Carcinogenesis 1989;10(6):1003-8.

32. Susanti RF, Kurnia K, Vania A, Reynald IJ. Total phenol, flavanoid and antioxidant activity of Physalis angulata leaves extract by subcritical water extraction. Mod Appl Sci 2015;9(7):190-8.

33. Saxena V, Mishra G, Saxena A, Vishwakarma KK. A comparative study on quantitative estimation of tannins in Terminalia chebula, Terminalia belerica, Terminalia arjuna and Saraca indica using spectrophotometer. Asian J Pharm Clin Res 2013;6(3):148-9.

34. Halliwell B. Reactive oxygen species in living systems: Source, biochemistry, and role in human disease. Am J Med 1991;91(3C):14S-22

35. Keser S, Celik S, Turkoglu S, Yilmaz O, Turkoglu I. Hydrogen peroxide radical scavenging and total antioxidant activity of Hawthorn. Chem J 2012;2(1):9-12. 